\title{
LETTER TO THE EDITOR GENOTYPING OF VARICELLA ZOSTER VIRUS CLINICAL ISOLATES FROM THE CZECH REPUBLIC
}

\author{
Vanda Boštíková', ${ }^{2}$, Radek Sleha', Pavel Boštík ${ }^{1}$ \\ ${ }^{1}$ Faculty of Military Health Sciences, University of Defence, Hradec Králové, Czech Republic \\ ${ }^{2}$ Faculty of Informatics and Management, University of Hradec Králové, Hradec Králové, Czech Republic
}

\begin{abstract}
Address for correspondence: V. Boštiková, Faculty of Military Health Sciences, University of Defence, Třebešská 1575, 50001 Hradec Králové, Czech Republic. E-mail: vanda.bostikova@unob.cz
\end{abstract}

http://dx.doi.org/10.21101/cejph.a4307

Varicella zoster virus (VZV) is a highly contagious human pathogen. Virus causes varicella (chickenpox) as a primary infection during which a lifelong latent infection is established. It is easily passed through airborne particles, droplets in exhaled air and fluids from blisters or sores. Virus can be also transmitted indirectly by a contact with articles of clothing and other items exposed to virus (1).

Around 45,000 cases of varicella are reported each year in the Czech Republic, which makes it the most frequent type of virus infection. The group infected most frequently in our temperate climate are children under 10 years of age (2). In adults, complications are more frequent in pregnant women, with negative consequences for the foetus and the newborns, and in immunocompromised people with an increased risk of mortality. Immunocompromised patients may develop severe skin eruptions with or without hemorrhage. Healing of the cutaneous lesions takes longer than in the general population. Patients often develop high fever. Virus spreads to visceral organs causing hepatitis, pneumonitis, pancreatitis, and encephalitis. Bacterial superinfections (Streptococcus pneumoniae, Haemophilus influenzae, Staphylococcus aureus) including bacteremia can develop (3).

A lifelong latent infection can reactivate, typically after the age of fifty, to cause herpes zoster (shingles). Herpes zoster occurs frequently in adults, but is not uncommon in immunocompromised and even normal children. In addition herpes zoster could be responsible for a wide spectrum of serious health complications. Immunocompromised patients can experience more severe forms of the disease. Lesions form for up to 2 weeks after infection and scabbing occurs until 3 to 4 weeks into the course of the disease. Patients with lymphoproliferative malignancies are at risk of cutaneous dissemination and visceral involvement, including pneumonitis, hepatitis, and meningoencephalitis. Around ten percent of patients with HIV can be infected with zoster. These patients can develop chronic herpes zoster, with formation of new lesions without healing of the already existing ones (4).

From 2009 to 2016, we examined 1,074 out- and inpatients with varicella (623 patients, $2.9 \%$ of immunocompromised) or herpes zoster (451 patients, $7.9 \%$ of immunocompromised) treated in the Faculty Hospital Hradec Králové.

Characterization of individual short VZV DNA sequences was performed utilizing PCR and sequencing. Single nucleotide polymorphisms (SNP) in open reading frames (ORF) 21, 22 and 50 were used to identify individual VZV strains (Table 1). All clinical isolates were VZV positive wild-type strains. The phylogenetic analysis showed that $33.7 \%$ of the clinical isolates were European clade 1 (C/E1strain) and $65.7 \%$ were European clade 3 (B/E2 strain). In this large cohort we have found six patients $(0.6 \%)$ infected with clade $5(\mathrm{~A} / \mathrm{M} 1$ strain). This clade is found mostly throughout Africa and India. Five of these clinical isolates were adults with manifestations of herpes zoster. The sixth case was 8 years old immunocompromised girl with varicella. Child was vaccinated by only one dose (instead of two) of Varilrix at the age of two. Varicella vaccination is not included in the Czech National Immunization Programme for children. The vaccination rate in Czech children is very low, around $1-2 \%$. This clinical sample was genotyped by sequencing as clade 5 containing unique SNP at position $95333 \mathrm{nt}$ (ORF 54) - T $>\mathrm{C} \mathrm{(5-8).}$

In the Czech Republic, the most common clades of VZV are European clades 1 and 3. Similar data have been repeatedly reported in Germany. They have shown $85 \%$ prevalence of clade 1 and 3 and nearly $20 \%$ of clade 1 replaced by clade 5 in primary VZV infection. Our findings of clade 5 in the Czech population support their hypothesis that the spread of clade 5 has been continuing throughout the European continent $(9,10)$.

Table 1. Single nucleotide polymorphisms in VZV strains detected in Czech patients with varicella or herpes zoster in comparison to reference Dumas strain (accession number X04370)

\begin{tabular}{|l|c|c|c|c|c|}
\hline \multirow{2}{*}{ ORF } & \multirow{2}{*}{ Position } & Clade 1 & Clade 3 & Clade 5 & $\begin{array}{c}\text { Reference } \\
\text { strain }\end{array}$ \\
\cline { 3 - 6 } & & E1/C & E2/B & M1/A & Dumas \\
\hline \multirow{2}{*}{ ORF 21 } & 33725 & $\mathrm{~T}$ & $\mathrm{C}$ & $\mathrm{C}$ & $\mathrm{T}$ \\
\cline { 2 - 6 } & 33728 & $\mathrm{~T}$ & $\mathrm{C}$ & $\mathrm{C}$ & $\mathrm{T}$ \\
\hline \multirow{3}{*}{ ORF 22 } & 37902 & $\mathrm{~A}$ & $\mathrm{~A}$ & $\mathrm{~A}$ & $\mathrm{~A}$ \\
\cline { 2 - 6 } & 38055 & $\mathrm{~T}$ & $\mathrm{~T}$ & $\mathrm{~T}$ & $\mathrm{~T}$ \\
\cline { 2 - 6 } & 38081 & $\mathrm{~A}$ & $\mathrm{~A}$ & $\mathrm{C}$ & $\mathrm{A}$ \\
\cline { 2 - 6 } & 38177 & $\mathrm{G}$ & $\mathrm{G}$ & $\mathrm{G}$ & $\mathrm{G}$ \\
\hline ORF 50 & 87841 & $\mathrm{C}$ & $\mathrm{T}$ & $\mathrm{T}$ & $\mathrm{C}$ \\
\hline
\end{tabular}


The global surveillance of VZV clades is important tool to increase our knowledge of the spread of individual clades and may potentially lead to better understanding of virulence issues. In conclusion, more clinical studies are necessary to make any general predictions.

\section{Acknowledgement}

This work was supported by grant P304/10/1161 from the Grant Agency of the Czech Republic, SVFVZ/2015, DRZHN.

\section{REFERENCES}

1. Arvin AM, Moffat JF, Redman R. Varicella-zoster virus: aspects of pathogenesis and host response to natural infection and varicella vaccine. Adv Virus Res. 1996;46:263-309.

2. National Institute of Public Health. Infections in CR - EPIDAT [Internet]. Prague: NIPH [cited 2016 Aug 28]. Available from: http://www.szu.cz/ publikace/data/infekce-v-cr. (In Czech.)

3. Boštíková V, Salavec M, Smetana J, Sleha R, Coufalová M, Spliňo M, et al. Infections caused by human alpha herpes viruses. Epidemiol Mikrobiol Imunol. 2014 Sep;63(3):206-13. (In Czech.)

4. Smetana J, Salavec M, Bostíková V, Chlíbek R, Bostík P, Hanovcová I, et al. Herpes zoster in the Czech Republic - epidemiology and clinical manifestations. Epidemiol Mikrobiol Imunol. 2010 Aug;59(3):138-46. (In Czech.)
5. Bostikova V, Salavec M, Smetana J, Chlibek R, Kosina P, Prasil P, et al. An unusual case of multi-recurrent herpes zoster (Hz): a case report. Biomed Pap Med Fac Univ Palacky Olomouc Czech Repub. 2011 Dec;155(4):397-401.

6. Bostikova V, Salavec M, Smetana J, Chlibek R, Kosina P, Prasil P, et al. Genotyping of varicella-zoster virus (vzv) wild-type strains isolated in the Czech Republic. Biomed Pap Med Fac Univ Palacky Olomouc Czech Repub. 2011 Dec;155(4):379-84

7. Boštíková V, Chlíbek R, Salavec M, Smetana J, Sleha R, Špliňo M, et al. Molecular biological and epidemiological -characteristics of the varicellazoster virus (VZV). Epidemiol Mikrobiol Imunol. 2013 Dec;62(4):14852. (In Czech.)

8. Bostik V, Prasil P, Plisek S, Kracmarova R, Kosina P, Salavec M, et al. Breakthrough varicella zoster virus infection in an immunized child with cystic fibrosis. Pediatr Infect Dis J. 2016 May;35(5):595-6.

9. Sauerbrei A, Stefanski J, Philipps A, Krumbholz A, Zell R, Wutzler P. Monitoring prevalence of varicella-zoster virus clades in Germany. Med Microbiol Immunol. 2011 May;200(2):99-107.

10. Kolesnik M, Sauerbrei A, Franke I, König W, Gollnick H, Bonnekoh B. Varicella outbreak in Indian students in Magdeburg with detection of the African-Indian VZV clade 5. J Dtsch Dermatol Ges. 2011 Jun;9(6):444-7.

Received February 16, 2015 Accepted in revised form August 28, 2016 